Article

\title{
Electro-Decontamination of Spent Ion Exchange Resins Contaminated with Iron Oxide Deposits under Dynamic Conditions
}

\author{
Eduard Tokar $\mathbb{D}$, Anna Matskevich and Andrei Egorin * $\mathbb{D}$
}

Institute of Chemistry, Far Eastern Branch, Russian Academy of Sciences, Prospect 100-letiya Vladivostok, 159, 690022 Vladivostok, Russia; d.edd@mail.ru (E.T.); mysmatskevich@mail.ru (A.M.)

* Correspondence: andrey.egorin@gmail.com

\begin{abstract}
A method for the electro-decontamination of spent ion exchange resin contaminated with hematite under dynamic conditions using sulfuric acid solutions has been suggested. It has been shown that decontamination under dynamic conditions excludes the secondary adsorption of radionuclides on ion-exchanger sites. The efficiency of this approach has been compared to that of control experiments without direct current treatment. A positive effect of the introduction of $\mathrm{Fe} 2+$ on the rate of dissolution of hematite has been demonstrated. This allows for decreasing the concentration of the sulfuric acid solution without decreasing the decontamination efficiency.
\end{abstract}

Keywords: ion-exchange resin; decontamination; direct-count; hematite

\section{Introduction}

The steel elements of a nuclear power plant (NPP) continue to become partially

Citation: Tokar, E.; Matskevich, A.; Egorin, A. Electro-Decontamination of Spent Ion Exchange Resins Contaminated with Iron Oxide Deposits under Dynamic Conditions. Sustainability 2021, 13, 4756. https:// doi.org/10.3390/su13094756

Academic Editor: Alireza Eivazi

Received: 12 March 2021

Accepted: 20 April 2021

Published: 23 April 2021

Publisher's Note: MDPI stays neutral with regard to jurisdictional claims in published maps and institutional affiliations. corroded in the course of its service. As a result of this process and subsequent hydrolysis, iron oxide/hydroxide particles are formed in the condensation water [1,2]. Such particles, generally called "crud", have a mixed chemical composition, which is mainly represented by iron and, to a lesser extent, chromium, nickel, cobalt, and zinc [3,4]. Crud particles tend to adsorb short-lived radionuclides of the corrosion group [3], which leads to the risk of receiving increased dose loads for maintenance personnel. The crud is removed from the NPP system water by means of mechanical filtration on columns with ion-exchange resins, followed by reverse washing. In the process of mechanical filtration, some parts of the crud bind irreversibly due to diffusion in the pore space of an ion-exchange resin grain [5], which complicates the regeneration and subsequent disposal of spent ion-exchange resins (SIER).

The utilization of SIER by direct immobilization into cement matrices and the use of thermal destruction methods (pyrolysis, combustion) demonstrate a number of substantial disadvantages, such as a decrease in the strength of cement matrices, as well as the formation of secondary gaseous products [6-8]. Liquid-phase oxidation based on the Fenton or electro-Fenton process, accompanied by the destruction of ion-exchanger due to depolymerization $[9,10]$, is free of these disadvantages. Possible disadvantages of liquid-phase oxidation include the use of concentrated solutions of hydrogen peroxide, the incomplete dissolution of SIER, and the formation of secondary liquid waste containing ion-exchanger decomposition products.

The removal of iron oxide deposits without destroying the polymer matrix represents a promising approach to SIER decontamination. For example, SIER contaminated with crud are treated by $\mathrm{HNO}_{3}$ and $\mathrm{H}_{2} \mathrm{SO}_{4}$ solutions at heating $\left(80-120{ }^{\circ} \mathrm{C}\right)[11,12]$ or citrate solutions with the addition of ascorbic acid $[13,14]$. Upon decontamination, Co-60 can be removed from acidic solutions by electrodeposition on a cathode [11,12]. Thereafter, decontaminated SIER can be dumped at a domestic waste disposal site [15].

The efficiency of the SIER decontamination by methods not involved in the destruction of the polymer matrix depends on the degree of removal of iron oxide deposits, which, 
in its turn, is determined by the completeness of the dissolution of hematite formed by the oxidation of magnetite with dissolved oxygen [2] or due to the transformation of goethite [1]. A significant issue here lies in the fact that it is difficult to dissolve hematite in mineral acids and in the presence of chelating agents, such as EDTA, IDA, and NTA, compared to goethite and magnetite [16-18].

In our opinion, the optimal method for decontaminating SIER contaminated with iron oxide deposits consists of treatment in the near-cathode reduction space in solutions of mineral acids under static conditions without adding organic impurities. The potential of such an approach was demonstrated in [19]. The dissolution of hematite occurs in accordance with the following reactions:

1. $2 \mathrm{H}^{+}+2 \overline{\mathrm{e}} \rightarrow 2 \mathrm{H}_{2} \uparrow$ (cathode),

2. $2 \mathrm{H}_{2} \mathrm{O}-4 \overline{\mathrm{e}} \rightarrow \mathrm{O}_{2} \uparrow+4 \mathrm{H}^{+}$(anode),

3. $\mathrm{Fe}_{2} \mathrm{O}_{3}+6 \mathrm{H}^{+}+2 \overline{\mathrm{e}} \rightarrow 2 \mathrm{Fe}^{2+}(\mathrm{aq})+3 \mathrm{H}_{2} \mathrm{O}[20]$.

Thus, the dissolution of hematite is intensified in the near-cathode space due to the reduction processes. It is worth mentioning that, after the hematite dissolution, the cobalt radionuclides enter the solution in an ionic form and can bind to the ion-exchanger exchange groups. In order to regenerate SIER and remove the radionuclide, it is necessary to additionally wash it with acid solutions containing an excess of sodium ions [19], which yields an increase in the volume of secondary waste. To solve this problem, the electrodecontamination of SIER can be carried out directly under dynamic conditions, which will prevent the secondary adsorption of cobalt radionuclide. Hence, the objective of the present work is to evaluate the efficiency of the SIER electro-decontamination process carried out under dynamic conditions.

\section{Materials and Methods}

Iron(III) chloride $\left(\mathrm{FeCl}_{3} \times 6 \mathrm{H}_{2} \mathrm{O}\right)$, iron (II) sulfate $\left(\mathrm{FeSO}_{4} \times 7 \mathrm{H}_{2} \mathrm{O}\right)$, ammonium hydroxide $\left(\mathrm{NH}_{4} \mathrm{OH}\right)$, a solution of sulfuric acid at a concentration of $17.5 \mathrm{~mol} / \mathrm{L}\left(\mathrm{H}_{2} \mathrm{SO}_{4}\right)$, and a solution of nitric acid at a concentration of $13.3 \mathrm{~mol} / \mathrm{L}\left(\mathrm{HNO}_{3}\right)$ of chemically pure grade were purchased from NevaReaktiv, Russia, and used without additional purification. The radionuclide Co-57 in $1 \mathrm{~mL}$ of $1 \mathrm{M} \mathrm{HCl}$ solution with an activity of $5 \mathrm{MBq}\left(1.6 \times 10^{-8} \mathrm{~g}\right.$ of Co-57) was acquired from the Leypunskiy Institute of Physics and Power Engineering. The KU 2-8 cation-exchanger was purchased from TOKEM, Russia. Prior to the start of the experiment, the cation-exchanger was washed with a $1 \mathrm{M}$ solution of $\mathrm{HNO}_{3}$ under dynamic conditions; thereafter, it was washed free from the acid residues with distilled water and stored in a flask with a plug stopper.

Model SIER were prepared according to the method described in [21]. The ion exchange resin KU 2-8 was pre-saturated with the radionuclide Co-57. For this purpose, $50 \mathrm{~mL}$ of Na-form ion-exchanger was transferred to a glass column, and distilled water labeled with the Co-57 radionuclide was fed through it at a rate of $30 \mathrm{~mL} / \mathrm{h}$. The ionexchanger containing the radionuclide Co-57 was transferred to a conical flask containing $250 \mathrm{~mL}$ of $\mathrm{FeCl}_{3}$ solution of a concentration of $0.2 \mathrm{~mol} / \mathrm{L}$; then, the resulting pulp was stirred for $24 \mathrm{~h}$. After the specified time, the pulp was alkalized with a $\mathrm{NH}_{4} \mathrm{OH}$ solution at a concentration of $10 \mathrm{~mol} / \mathrm{L}$ to a neutral reaction and held for 3-6 h. After acidification with $\mathrm{HCl}$ solution to $\mathrm{pH} 2$, the pulp was transferred to a stainless steel autoclave with an inner Teflon chamber and hydrothermally treated for $24 \mathrm{~h}$ at a temperature of $175^{\circ} \mathrm{C}$. The hydrothermal treatment leads to the formation of a hematite phase (card number No. 00-210-8027) on the surface and in the bulk of the resin grains (Figure 1).

After the treatment, the model SIER was washed by decanting from the remains of hematite particles formed outside an ion-exchanger grain, then treated under dynamic conditions with a solution of the following composition: $\mathrm{HNO}_{3}-3 \mathrm{~mol} / \mathrm{L}, \mathrm{NaNO}_{3}-$ $1 \mathrm{~mol} / \mathrm{L}$ with a volume of $500 \mathrm{~mL}$.

The experiments were performed using an electrochemical cell with a volume of $45 \mathrm{~mL}$; the working volume was $30 \mathrm{~mL}$ (Figure 2). The cell consisted of two interconnected segments, where an anode in the form of a plate and a spiral cathode were placed. The 
near-cathode space was additionally contained by a glass cylinder of an internal diameter of $1.2 \mathrm{~cm}$ with a cross-linked bottom made of a chemically resistant polymer. For further treatment, $2 \mathrm{~mL}$ of the model SIER was placed in a glass cylinder.

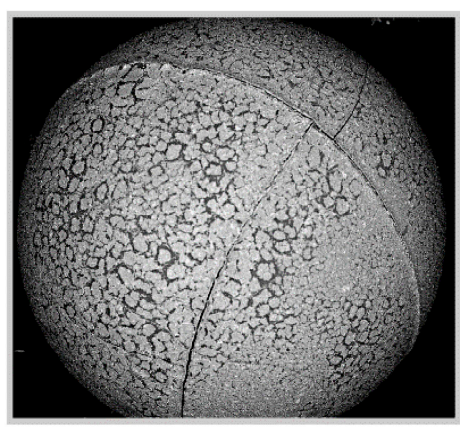

(a)

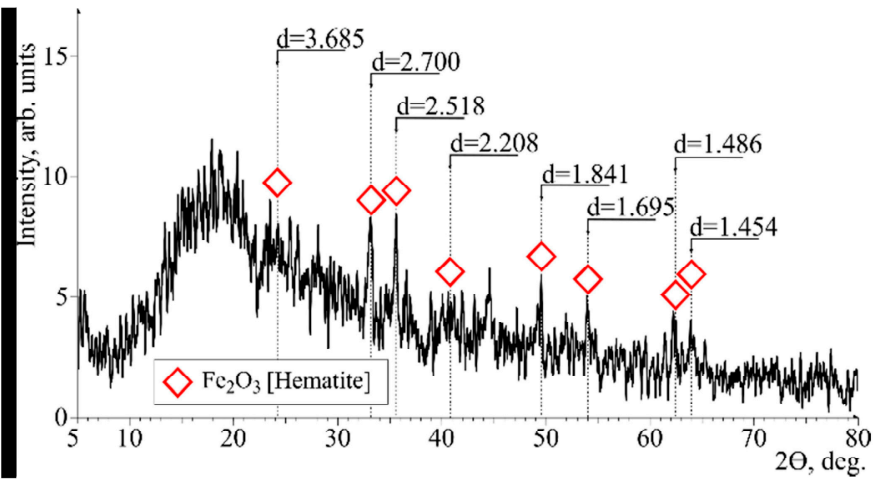

(b)

Figure 1. Model SIER: (a) SEM; (b) XRD pattern.

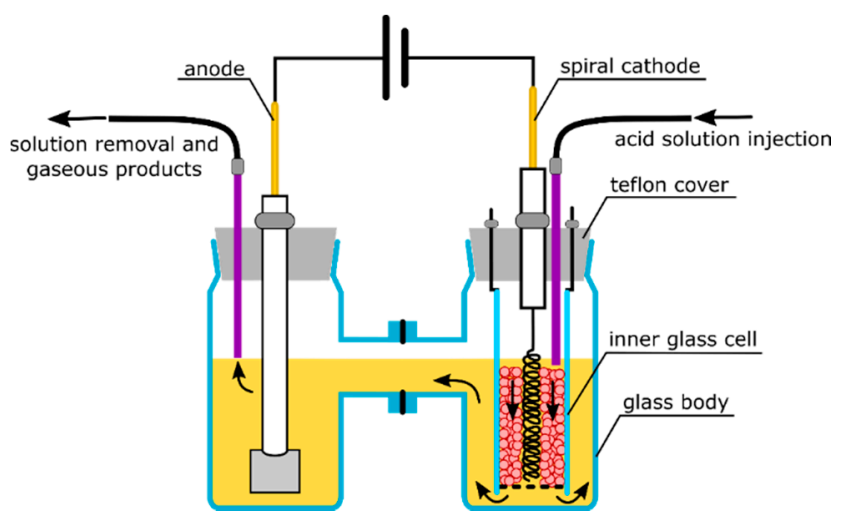

Figure 2. Design of the electrochemical cell for the decontamination of the model SIER under dynamic conditions.

The treatment of the model SIER under dynamic conditions was performed by feeding $\mathrm{H}_{2} \mathrm{SO}_{4}$ solution through the cell at a rate of $4 \mathrm{~mL} / \mathrm{h}$. It was then collected using a fraction collector, and the specific activity of Co-57 was measured. The electro-decontamination process was accompanied by the partial flaking-off of hematite from the surface of the model SIER and its delivery from the inner glass cell into the glass body. The flaked-off hematite residue was removed from the cell; then, the specific activity $(R A)$ was measured. During the treatment, the cell was heated up; then, it was placed in a container with water to cool down to room temperature $\left(22 \pm 5{ }^{\circ} \mathrm{C}\right)$. The temperature inside the cell was continuously monitored using an electronic thermometer.

The total decontamination efficiency $(s D E)$ was calculated using Equation (1):

$$
\operatorname{sDE}(\%)=\left(\frac{\sum_{V=0}^{n}\left(V \times A_{i}\right)}{A_{0}}\right) \times 100,
$$

where $V$ is the amount of solution passed through the cell at the time of measurement $(\mathrm{mL}), A_{i}$ is the activity of the passed solution $(\mathrm{DPM} / \mathrm{mL})$, and $n$ is the total amount of the solution passed through the cell $(\mathrm{mL})$.

To describe the decontamination process of the model SIER under dynamic conditions, the logistic equation (2) was used to describe the experimental values in the coordinates $A / A_{0}=f(V)$ : 


$$
\frac{A}{A_{0}}=\frac{G}{1+e^{-\frac{V-A}{B}}},
$$

where $A_{0}$ is the total activity of the model SIER (DPM), $A$ is the activity of the fraction of the fed solution (DPM), $G$ is the maximum expected desorption efficiency (unit fraction), $V$ is the volume of the passed solution $(\mathrm{mL}), A$ is the volume of the $\mathrm{H}_{2} \mathrm{SO}_{4}$ solution required to be fed through the resin to achieve a decontamination efficiency of $50 \%(\mathrm{~mL}), B$ is the dimensionless coefficient inverse to the exponential growth value.

The control experiment without electro-decontamination was carried out as follows: a model SIER of a volume of $2 \mathrm{~mL}$ was placed in a glass column with an internal diameter of $1.2 \mathrm{~cm}$. The $\mathrm{H}_{2} \mathrm{SO}_{4}$ solution was fed through the column at a rate of $2 \mathrm{~mL} / \mathrm{h}$. The filtrate was collected using a fraction collector, and the activity of Co-57 was measured.

The accuracy of the measurement of the activity of model SIER and solution fed through the cell was estimated through the determination of the confidence interval $\left(\mathrm{CI}_{0.95}\right)$ with the confidence level of $0.95(p<0.05)$ as a standard deviation of $\times 1.96$ in accordance with Equation (3):

$$
C I_{0.95}=\frac{\sqrt{n}}{t} \times 1.96,
$$

where $n$ is the quantity of registered impulses and $t$ is the measurement time (min).

The specific activity of Co-57 (photopeak energy: $122 \mathrm{keV}$ ) was determined by the direct radiometric method using an RKG-AT1320 gamma-radiometer equipped with a $\mathrm{NaI}(\mathrm{Tl})$ detector measuring $63 \times 63 \mathrm{~mm}$ (RPE Atomtech, Republic of Belarus). The X-ray phase analysis was performed using a D8 ADVANCE diffractometer, $\mathrm{X}$-ray images of the samples were recorded in the range of angles $2 \theta 3-85^{\circ}$ with a step of $0.02^{\circ}$ at the count point of $0.6 \mathrm{~s}$. The phase composition was identified using the Qualx2. 0 software. The results were processed using the SciDAVis software (ver 1.23).

\section{Results}

Figure 3 shows decontamination curves without electro-decontamination, which was carried out by feeding the $\mathrm{H}_{2} \mathrm{SO}_{4}$ solution through a fixed layer of the model SIER placed in the column. The experimental parameters and the logistic equation coefficients are summarized in Table 1.

Table 1. Decontamination efficiency and coefficients obtained by approximating the experimental data using the logistic equation without electro-decontamination.

\begin{tabular}{cccccccc}
\hline Experiment & $\begin{array}{c}\mathrm{FeSO}_{4} \\
(\mathbf{m o l} / \mathbf{L})\end{array}$ & $\begin{array}{c}\mathbf{H}_{2} \mathbf{S O}_{4} \\
(\mathbf{m o l} / \mathbf{L})\end{array}$ & $\boldsymbol{G}$ & $\boldsymbol{A}$ & $\boldsymbol{B}$ & $\mathbf{R}^{2}$ & sDE \\
\hline 1 & - & 1 & $1.0 \pm 0.02$ & $54.6 \pm 0.8$ & $14.3 \pm 0.5$ & 0.9971 & 96.6 \\
2 & - & 2 & $1.02 \pm 0.01$ & $50.4 \pm 0.7$ & $13.9 \pm 0.6$ & 0.9972 & 97.5 \\
3 & 0.1 & 1 & $1.02 \pm 0.01$ & $46.7 \pm 0.6$ & $11.7 \pm 0.5$ & 0.9971 & 98.8 \\
4 & 0.1 & 2 & $1.0 \pm 0.02$ & $40.0 \pm 0.6$ & $8.8 \pm 0.4$ & 0.9967 & 98.9 \\
\hline
\end{tabular}

The experimental data are adequately described by an S-type logistic curve $\left(R^{2}>0.95\right)$.

Figure 4 shows the results of the electro-decontamination of the model SIER in the presence of $\mathrm{H}_{2} \mathrm{SO}_{4}$ solutions: the experimental conditions and the calculated values of the logistic equation are provided in Table 2.

The experimental data obtained using electro-decontamination are also adequately described by the logistic equation; however, the curve shape is different, which indicates changes in the rate and character of hematite dissolution. 


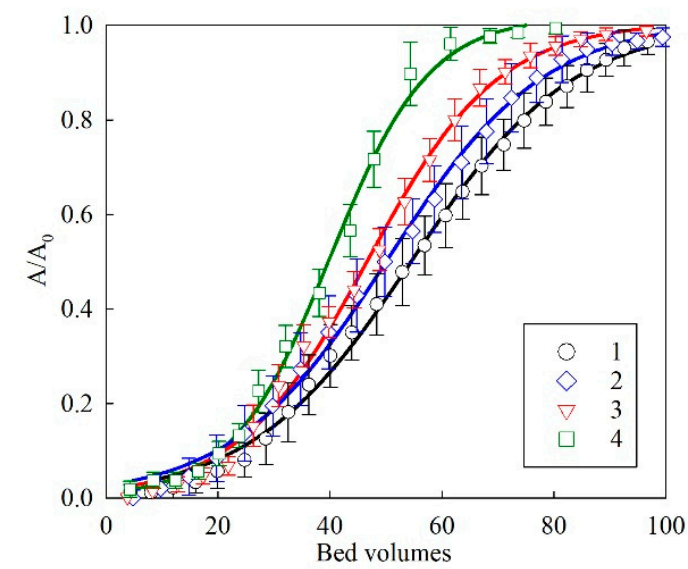

Figure 3. Decontamination curves for the model SIER: 1: experiment No. $1\left(\mathrm{H}_{2} \mathrm{SO}_{4}: 1 \mathrm{~mol} / \mathrm{L}\right)$; 2 : experiment No. $2\left(\mathrm{H}_{2} \mathrm{SO}_{4}: 2 \mathrm{~mol} / \mathrm{L}\right)$; 3: experiment No. $3\left(\mathrm{H}_{2} \mathrm{SO}_{4}: 1 \mathrm{~mol} / \mathrm{L} ; \mathrm{FeSO}_{4}: 0.1 \mathrm{~mol} / \mathrm{L}\right) ; 4$ : experiment No. $4\left(\mathrm{H}_{2} \mathrm{SO}_{4}: 2 \mathrm{~mol} / \mathrm{L} ; \mathrm{FeSO}_{4}: 0.1 \mathrm{~mol} / \mathrm{L}\right)$.

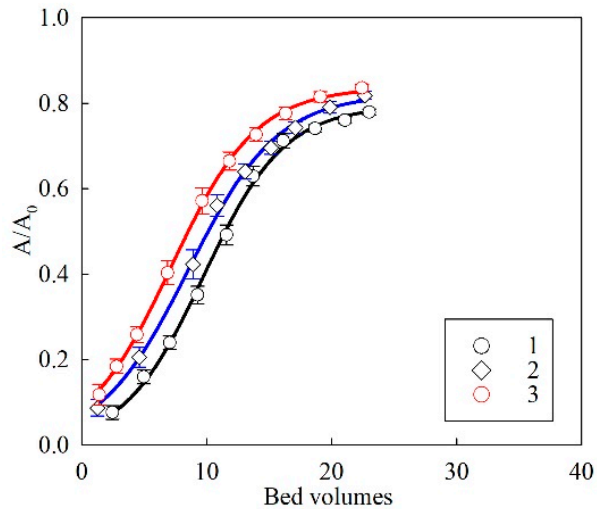

(a)

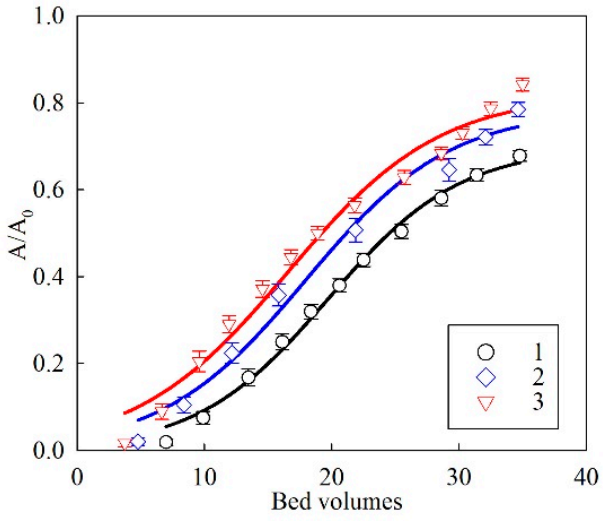

(b)

Figure 4. Decontamination of the ion exchange resin under dynamic conditions: (a) $\mathrm{H}_{2} \mathrm{SO}_{4}: 1 \mathrm{~mol} / \mathrm{L} ;(\mathbf{b}) \mathrm{H}_{2} \mathrm{SO}_{4:} 2 \mathrm{~mol} / \mathrm{L} ; 1$ : 1A; 2: $1.5 \mathrm{~A} ; 3: 2 \mathrm{~A}$.

Table 2. Decontamination efficiency and coefficients obtained by approximating the experimental data using the logistic equation.

\begin{tabular}{ccccccccc}
\hline Experiment & $\begin{array}{c}\mathbf{H}_{\mathbf{2}} \mathbf{S O}_{4} \\
(\mathbf{m o l} / \mathbf{L})\end{array}$ & $\begin{array}{c}\text { Current } \\
\text { (A) }\end{array}$ & $\boldsymbol{G}$ & $\boldsymbol{A}$ & $\boldsymbol{B}$ & $\mathbf{R}^{\mathbf{2}}$ & $\boldsymbol{R A}$ & $\boldsymbol{s D E}$ \\
\hline 5 & 1 & 1.0 & $0.70 \pm 0.02$ & $19.7 \pm 0.5$ & $5.2 \pm 0.4$ & 0.9940 & 22 & 91.5 \\
6 & 1 & 1.5 & $0.78 \pm 0.05$ & $18.0 \pm 1.3$ & $5.7 \pm 1.0$ & 0.9861 & 14 & 92.2 \\
7 & 1 & 2.0 & $0.82 \pm 0.04$ & $17.0 \pm 1.0$ & $6.0 \pm 0.8$ & 0.9799 & 10 & 9.5 \\
8 & 2 & 1.0 & $0.80 \pm 0.01$ & $10.0 \pm 0.2$ & $3.2 \pm 0.1$ & 0.9981 & 17 & 97.4 \\
9 & 2 & 1.5 & $0.82 \pm 0.01$ & $8.5 \pm 0.2$ & $3.6 \pm 0.2$ & 0.9980 & 16 & 98.4 \\
10 & 2 & 2.0 & $0.84 \pm 0.01$ & $7.2 \pm 0.1$ & $3.4 \pm 0.1$ & 0.9993 & 14 & 98.4 \\
\hline
\end{tabular}

The effect of $\mathrm{Fe}^{2+}\left(\mathrm{FeSO}_{4}\right)$ on the efficiency and rate of the decontamination of the model SIER under dynamic conditions was evaluated. The results are shown in Figure 5; the experimental conditions and the calculated values of the logistic equation are provided in Table 3.

Figure 6 shows the gamma spectra of the model SIER before the treatment and after electro-decontamination under dynamic conditions (experiment 12) in comparison with the background spectrum. 


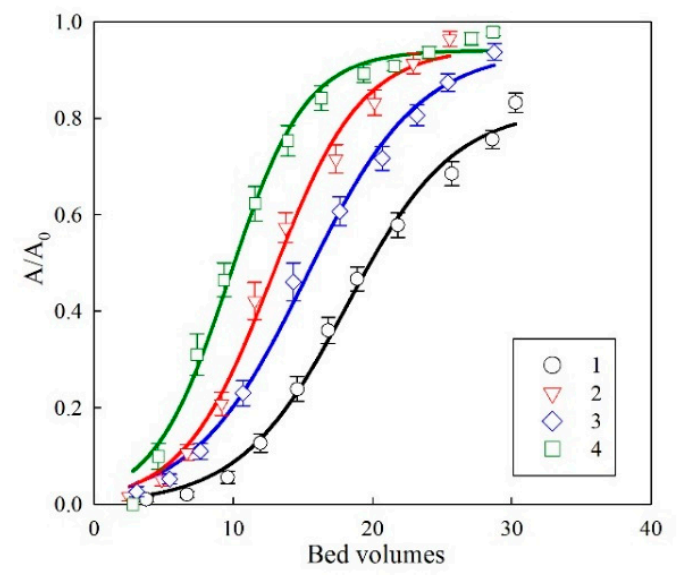

Figure 5. Decontamination of the model SIER under dynamic conditions in the presence of $\mathrm{Fe}^{2+}$, current of 1.5 A. 1: $\mathrm{H}_{2} \mathrm{SO}_{4}, 1 \mathrm{~mol} / \mathrm{L} ; \mathrm{FeSO}_{4}, 0.1 \mathrm{~mol} / \mathrm{L} .2: \mathrm{H}_{2} \mathrm{SO}_{4}, 2 \mathrm{~mol} / \mathrm{L} ; \mathrm{FeSO}_{4}, 0.1 \mathrm{~mol} / \mathrm{L} .3$ : $\mathrm{H}_{2} \mathrm{SO}_{4}, 1 \mathrm{~mol} / \mathrm{L} ; \mathrm{FeSO}_{4}, 0.2 \mathrm{~mol} / \mathrm{L} .4: \mathrm{H}_{2} \mathrm{SO}_{4}, 2 \mathrm{~mol} / \mathrm{L} ; \mathrm{FeSO}_{4}, 0.2 \mathrm{~mol} / \mathrm{L}$.

Table 3. Decontamination efficiency and coefficients obtained by approximating the experimental data using the logistic equation.

\begin{tabular}{cccccccccc}
\hline Experiment & $\begin{array}{c}\mathrm{FeSO}_{4} \\
(\mathbf{m o l} / \mathbf{L})\end{array}$ & $\begin{array}{c}\mathbf{H}_{\mathbf{2}} \mathbf{S O}_{\mathbf{4}} \\
(\mathbf{m o l} / \mathbf{L})\end{array}$ & $\begin{array}{c}\text { Current } \\
\text { (A) }\end{array}$ & $\boldsymbol{G}$ & $\boldsymbol{A}$ & $\boldsymbol{B}$ & $\mathbf{R}^{\mathbf{2}}$ & $\boldsymbol{R A}$ & $\boldsymbol{s D E}$ \\
\hline 11 & 0.1 & 1 & 1.5 & $0.82 \pm 0.03$ & $18.1 \pm 0.4$ & $3.8 \pm 0.3$ & 0.9942 & 12 & 94.4 \\
12 & 0.1 & 2 & 1.5 & $0.95 \pm 0.03$ & $12.8 \pm 0.4$ & $3.2 \pm 0.3$ & 0.9931 & 3 & 97.9 \\
13 & 0.2 & 1 & 1.5 & $0.94 \pm 0.03$ & $15.2 \pm 0.4$ & $4.0 \pm 0.3$ & 0.9955 & 5 & 98.4 \\
14 & 0.2 & 2 & 1.5 & $0.94 \pm 0.02$ & $9.7 \pm 0.3$ & $2.7 \pm 0.2$ & 0.9918 & 4 & 98.5 \\
\hline
\end{tabular}

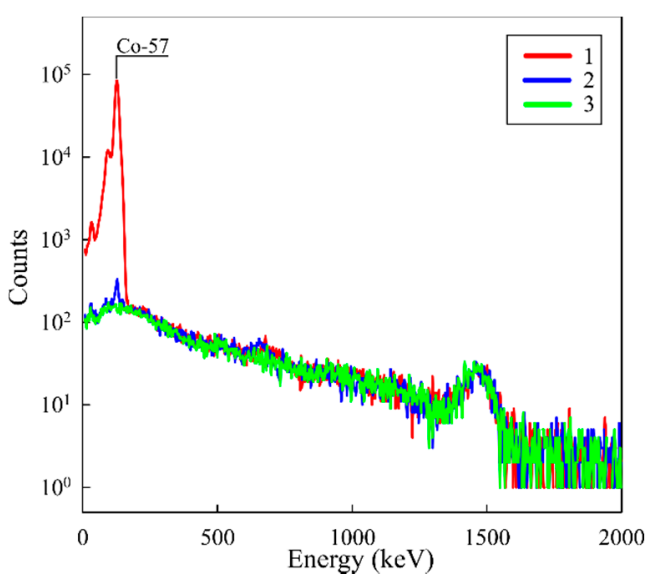

Figure 6. Gamma-spectra of the model resin. 1: spectrum of the initial model SIER; 2: spectrum after the treatment (experiment No. 13); 3: background spectrum.

\section{Discussion}

The experimental data obtained using $\mathrm{H}_{2} \mathrm{SO}_{4}$ solutions without electrochemical treatment are adequately described by the logistic curve with a high determination coefficient (Figure 3, Table 1). The $G$ values reach one whereas the actual decontamination efficiency exceeds $96 \%$, which indicates that $\mathrm{H}_{2} \mathrm{SO}_{4}$ solutions can be used for the effective removal of crud in the form of hematite deposits. By increasing the concentration of the $\mathrm{H}_{2} \mathrm{SO}_{4}$ solution, the decontamination efficiency increases insignificantly.

The introduction of $\mathrm{Fe}(\mathrm{II})$ to the $\mathrm{H}_{2} \mathrm{SO}_{4}$ solution can intensify the hematite dissolution process. This assumption is based on the fact that, in neutral media, Fe(II) is adsorbed on the surface of hematite with subsequent oxidation until $\mathrm{Fe}(\mathrm{III})$ and electron transfer to $\mathrm{Fe}(\mathrm{III})$, which forms a part of the crystal lattice. The electron density redistribution between 
$\mathrm{Fe}(\mathrm{II})$ and $\mathrm{Fe}(\mathrm{III})$ is accompanied by the formation of a new mineral phase in the form of magnetite [22]. P. Larese-Casanova et al. [23] also provided data on the adsorption of Fe(II) on hematite with the formation of the $\mathrm{Fe}(\mathrm{OH})_{2}$ phase. A. J. Frierdich [24] indicated that, along with a decrease of the size of hematite particles, the efficiency of Fe(II) adsorption increases due to the special features of the exchange. Here, on small particles, iron exchange occurs in their bulk, whereas, on large particles, adsorption occurs only in the surface layer [24]. J. G. Catalano et al. [25] stated that the oxidative adsorption of Fe(II) on hematite and the redistribution of electron density occur in acidic media as well. Here, the adsorption process is accompanied by structural changes in hematite. The possibility of the adsorption of $\mathrm{Fe}(\mathrm{II})$ from acidic media by hematite was confirmed by the results provided by B-H Jeon et al. [26].

To sum up, the preliminary introduction of $\mathrm{Fe}(\mathrm{II})$ to the $\mathrm{H}_{2} \mathrm{SO}_{4}$ solution can result in structural changes in hematite due to the adsorption and redistribution of electron density with subsequent formation of more soluble new phases, which, in its turn, can increase the solubility of iron oxide deposits on SIER. Indeed, it was found that the introduction of Fe(II) to the $\mathrm{H}_{2} \mathrm{SO}_{4}$ solution led to an increase in the intensity and completeness of the dissolution of hematite on the model SIER under dynamic conditions (Figure 3, lines 3, 4). It is worth mentioning that, despite satisfactory results, the disadvantage of this approach consists in the excessive consumption of the $\mathrm{H}_{2} \mathrm{SO}_{4}$ solution. To solve this problem, the intensity of dissolution of hematite deposits can be increased with the use of electro-decontamination of SIER.

In the course of electro-decontamination of SIER, the following features and regularities have been revealed. According to the values of the parameter $G$ of the logistic equation, an increase of the concentration of the $\mathrm{H}_{2} \mathrm{SO}_{4}$ solution from 1 to $2 \mathrm{~mol} / \mathrm{L}$ is accompanied by an increase in the efficiency of decontamination of the model SIER. It is worth mentioning, however, that the value of the $G$ parameter cannot reach $100 \%$ because a part of hematite is mechanically flaked off from the model SIER without dissolution, which leads to a decrease in the total activity of the solution fed through the cell. An increase of the concentration of the $\mathrm{H}_{2} \mathrm{SO}_{4}$ solution enables one to half the total volume of the solution (parameter $A$ ) required for $50 \%$ decontamination of the model SIER, as well as to double the rate of dissolution of hematite deposits-a decrease of the parameter $B$. A similar effect was observed with a growth of the DC current, which increases the efficiency and rate of the SIER decontamination with smaller volumes of acid solution. The $G$ value calculated using the logistic equation correlates to the actual residual activity of the model SIER, taking into account the residue of the undissolved hematite, whose weight and activity also depend on the treatment conditions. From the point of view of the actual efficiency of decontamination of the model SIER and the reduction in the cost for the direct current treatment, the most attractive treatment modes are No. 6 and No. 9. Therefore, further studies were performed at a DC power of $1.5 \mathrm{~A}$.

During electro-decontamination, the addition of $\mathrm{Fe}^{2+}$ led to inconclusive results. In particular, in the case of using the $\mathrm{H}_{2} \mathrm{SO}_{4}$ solution of a concentration of $2 \mathrm{~mol} / \mathrm{L}$, only an increase of the $G$ parameter was observed, whereas the values of $A$ and $B$ remained practically unchanged. This fact is related to the more complete dissolution of hematite deposits, which is corroborated by a decrease of the activity and, accordingly, the weight of the sediment remaining after the particles flaking-off. The residual activity of the model SIER, which is the most important indicator of the decontamination, also does not virtually change after the introduction of $\mathrm{Fe}^{2+}$.

A different picture is observed using the solution of $\mathrm{H}_{2} \mathrm{SO}_{4}$ of a concentration of $1 \mathrm{~mol} / \mathrm{L}$. The introduction of $\mathrm{Fe}^{2+}$ is accompanied by a decrease of the parameters $\mathrm{A}$ and $\mathrm{B}$, as well as by an increase of $\mathrm{G}$ and the efficiency of decontamination of the resin. These results are compatible with those obtained using the solution of $\mathrm{H}_{2} \mathrm{SO}_{4}$ of a concentration of $2 \mathrm{~mol} / \mathrm{L}$. To sum up, the addition of $\mathrm{Fe}^{2+}$ allows the use of more dilute solutions of $\mathrm{H}_{2} \mathrm{SO}_{4}$, which firstly reduces economic costs and secondly decreases the potential corrosion of equipment. After the treatment, the gamma spectrum of the treated model SIERRA 
almost coincides with the background spectrum, which corroborates the efficiency of this decontamination method. In theory, decontaminated resins can be disposed of as non-radioactive waste.

It is worth mentioning that the introduction of $\mathrm{Fe}(\mathrm{II})$ allows for the complete disposal of secondary liquid radioactive waste. Here, the alkalization of the solution that was used for the decontamination of the model SIER with $\mathrm{NH}_{4} \mathrm{OH}$ solution of a concentration of $3 \mathrm{~mol} / \mathrm{L}$ allows the complete deposition of $\mathrm{Co}-57$ on the iron hydroxide sediment. The resulting sediment can be easily immobilized into a cement matrix, and the non-radioactive solution can be disposed of as sanitary waste.

Table 4 shows the results of the comparison of the electro-decontamination of the model SIER under static and dynamic conditions. One can see that the decontamination under dynamic conditions eliminates the stage of additional washing of the resin, as well as reduces the volume of secondary liquid radioactive waste. The latter allows the process simplification as well as a reduction in the cost of decontamination of SIER with the use of electro-decontamination.

Table 4. Comparison of the volume of the solutions formed during decontamination of the model SIER under different conditions.

\begin{tabular}{|c|c|c|c|}
\hline \multirow{2}{*}{$\begin{array}{l}\text { Electro-Decontamination } \\
\text { Conditions }\end{array}$} & \multicolumn{2}{|c|}{ Solution } & \multirow{2}{*}{$\begin{array}{l}\text { The Solution/SIER } \\
\text { Ratio }(\mathrm{mL} / \mathrm{mL})\end{array}$} \\
\hline & $\begin{array}{c}\mathrm{H}_{2} \mathrm{SO}_{4} \\
(1 \mathrm{~mol} / \mathrm{L})\end{array}$ & $\begin{array}{l}\mathrm{NaNO}_{3}(2 \mathrm{~mol} / \mathrm{L}), \\
\mathrm{HNO}_{3}(1 \mathrm{~mol} / \mathrm{L})\end{array}$ & \\
\hline Static & $90 \pm 9$ & $30 \pm 3$ & 33 \\
\hline Dynamic & $30 \pm 10$ & 0 & 15 \\
\hline
\end{tabular}

\section{Conclusions}

The possibility of the decontamination of SIER contaminated with hematite deposits using $\mathrm{H}_{2} \mathrm{SO}_{4}$ solutions under dynamic conditions has been evaluated. Increasing the concentration of the $\mathrm{H}_{2} \mathrm{SO}_{4}$ solution and introducing $\mathrm{Fe}^{2+}\left(\mathrm{FeSO}_{4}\right)$ allows for improving the decontamination efficiency, which exceeds $96 \%$. The disadvantage of this approach consists of the excessive consumption of the $\mathrm{H}_{2} \mathrm{SO}_{4}$ solution. As a result, the ratio of the volume of acid to the volume of swollen SIER exceeds 80 , which can reduce the economic efficiency of this approach. The direct electric current treatment reduces the consumption of the $\mathrm{H}_{2} \mathrm{SO}_{4}$ solution more than twofold at a comparable efficiency to the SIER decontamination under dynamic conditions. For this purpose, the two-section electrochemical cell has been suggested. The introduction of $\mathrm{Fe}^{2+}$ in the form of $\mathrm{FeSO}_{4}$ to the $\mathrm{H}_{2} \mathrm{SO}_{4}$ solution of a concentration of $1 \mathrm{~mol} / \mathrm{L}$ during the electrochemical treatment increases the rate and efficiency of decontamination of the resin, which attains $98.4 \%$. These results are comparable to those obtained using the $\mathrm{H}_{2} \mathrm{SO}_{4}$ solution of a concentration of $2 \mathrm{~mol} / \mathrm{L}$. The latter, in theory, will allow the use of solutions of $\mathrm{H}_{2} \mathrm{SO}_{4}$ of a lower concentration, which will reduce the economic expense and decrease the corrosion of equipment. The results obtained can serve as a basis for creating a technology for the decontamination of actual SIER polluted with iron oxide deposits.

Author Contributions: Conceptualization, A.E.; Formal analysis, A.E., E.T.; Funding acquisition, A.E.; Investigation, E.T., A.M.; Methodology, A.E., E.T.; Writing—original draft, A.E.; Writing—review and editing, A.E., E.T. All authors have read and agreed to the published version of the manuscript.

Funding: The development and synthesis of materials were carried out with the financial support of the Russian Science Foundation (Project 18-73-10066).

Acknowledgments: Equipment of CUC "Far Eastern Center of Structural Investigations" was used in this work.

Conflicts of Interest: The authors declare no conflict of interest. 


\section{References}

1. Sawicki, J.A. Analyses of Fuel Crud and Coolant-Borne Corrosion Products in Normal Water Chemistry BWRs. J. Nucl. Mater. 2011, 419, 85-96. [CrossRef]

2. Sawicki, J.A.; Sefranek, P.J.; Fisher, S. Depth Distribution and Chemical Form of Iron in Low Cross-Linked Crud-Removing Resin Beds. Nucl. Instrum. Methods Phys. Res. Sect. B Beam Interact. Mater. At. 1998, 142, 122-132. [CrossRef]

3. Hoshi, M.; Tachikawa, E.; Suwa, T.; Sagawa, C.; Yonezawa, C.; Aoyama, I.; Yamamoto, K. Crud Behaviors in High-Temperature Water, (I): Characterization of Water in JMTR OWL-1 Loop. J. Nucl. Sci. Technol. 1986, 23, 511-521. [CrossRef]

4. Tsai, T.-L.; Lin, T.-Y.; Su, T.-Y.; Wei, H.-J.; Men, L.-C.; Wen, T.-J. Identification of Chemical Composition of CRUD Depositing on Fuel Surface of a Boiling Water Reactor (BWR-6) Plant. Energy Procedia 2012, 14, 867-872. [CrossRef]

5. Otoha, K.; Izumi, T.; Hayashi, T.; Morikawa, Y.; Murabayashi, H. Crud Removal Performance with Ion Exchange Resins in BWR Plants. J. Nucl. Sci. Technol. 1996, 33, 10. [CrossRef]

6. Li, J.; Wang, J. Advances in Cement Solidification Technology for Waste Radioactive Ion Exchange Resins: A Review. J. Hazard. Mater. 2006, 135, 443-448. [CrossRef]

7. Korpiola, K.; Järvinen, J.; Penttilä, K.; Kotiluoto, P. Modeling of Incineration of Spent Ion Exchange Resins of Boiling Water and Pressurized Water Nuclear Reactors. Nucl. Technol. 2010, 172, 230-236. [CrossRef]

8. Luca, V.; Bianchi, H.L.; Allevatto, F.; Vaccaro, J.O.; Alvarado, A. Low Temperature Pyrolysis of Simulated Spent Anion Exchange Resins. J. Environ. Chem. Eng. 2017, 5, 4165-4172. [CrossRef]

9. Xu, L.; Meng, X.; Li, M.; Li, W.; Sui, Z.; Wang, J.; Yang, J. Dissolution and Degradation of Nuclear Grade Cationic Exchange Resin by Fenton Oxidation Combining Experimental Results and DFT Calculations. Chem. Eng. J. 2019, 361, 1511-1523. [CrossRef]

10. Cheng, T.-H.; Huang, C.-P.; Huang, Y.-H.; Shih, Y.-J. Kinetic Study and Optimization of Electro-Fenton Process for Dissolution and Mineralization of Ion Exchange Resins. Chem. Eng. J. 2017, 308, 954-962. [CrossRef]

11. Kitabata, T.; Yoshimura, S.; Tsukamoto, Y.; Higashiura, N.; Mitsumori, S. Separation Method of Radionuclide from Spent Ion Exchange Resin. Patent No. JP2967026B2, 24 October 1999. Available online: https:/ / patents.google.com/patent/JP2967026B2/en (accessed on 19 April 2021).

12. Miyamoto, S.; Saki, M.; Aizawa, M.; Ota, N.; Sumitani, T.; Ishida, I. Decontamination Method and Decontamination Apparatus for Radioactive Waste Ion Exchange Resin. Patent No. JP6439242B2, 19 December 2018. Available online: https:/ / patents.google. $\mathrm{com} /$ patent/JP6439242B2/en?oq=JP6439242B2 (accessed on 19 April 2021).

13. Chi, L.; Semmler, J. Electrochemical Regeneration of Spent Ion Exchange Resin, Report number AECL-CW-127140-CONF-002; Atomic Energy of Canada Limited: Chalk River, ON, Canada, 2010; Available online: https://inis.iaea.org/search/search.aspx?orig_q= RN:49101522 (accessed on 3 March 2021).

14. Semmler, J.; Chi, L. Treatment of Liquid Waste and Regeneration of Spent Ion Exchange Resin Using Electrochemical Techniques, Report number AECL-CW-127140-CONF-003; Atomic Energy of Canada Limited: Chalk River, ON, Canada, 2012; Available online: https:/ / inis.iaea.org/search/search.aspx?orig_q=RN:49101523 (accessed on 3 March 2021).

15. Korchagin, Y.P.; Aref'ev, E.K.; Korchagin, E.Y. Improvement of Technology for Treatment of Spent Radioactive Ion-Exchange Resins at Nuclear Power Stations. Therm. Eng. 2010, 57, 593-597. [CrossRef]

16. Sidhu, P.S. Dissolution of Iron Oxides and Oxyhydroxides in Hydrochloric and Perchloric Acids. Clays Clay Miner. 1981, 29, 269-276. [CrossRef]

17. Torres, R.; Blesa, M.A.; Matijević, E. Interactions of Metal Hydrous Oxides with Chelating Agents: IX. Reductive Dissolution of Hermatite and Magnetite by Aminocarboxylic Acids. J. Colloid Interface Sci. 1990, 134, 475-485. [CrossRef]

18. Keny, S.J.; Kumbhar, A.G.; Venkateswaran, G.; Kishore, K. Radiation Effects on the Dissolution Kinetics of Magnetite and Hematite in EDTA- and NTA-Based Dilute Chemical Decontamination Formulations. Radiat. Phys. Chem. 2005, 72, 475-482. [CrossRef]

19. Tokar, E.A.; Matskevich, A.I.; Sokolnitskaya, T.A.; Egorin, A.M. The Dissolution of Hematite Deposits on Model Spent Ion Exchange Resins Using Direct Current. IOP Conf. Ser. Mater. Sci. Eng. 2021, 1048, 012020. [CrossRef]

20. Yanina, S.V.; Rosso, K.M. Linked Reactivity at Mineral-Water Interfaces Through Bulk Crystal Conduction. Science 2008, 320, 218-222. [CrossRef] [PubMed]

21. Egorin, A.; Tokar, E.; Kalashnikova, A.; Sokolnitskaya, T.; Tkachenko, I.; Matskevich, A.; Filatov, E.; Zemskova, L. Synthesis and Sorption Properties towards Sr-90 of Composite Sorbents Based on Magnetite and Hematite. Materials 2020, 13, 1189. [CrossRef]

22. Jeon, B.-H.; Dempsey, B.A.; Burgos, W.D. Kinetics and Mechanisms for Reactions of Fe(II) with Iron(III) Oxides. Environ. Sci. Technol. 2003, 37, 3309-3315. [CrossRef]

23. Larese-Casanova, P.; Scherer, M.M. Fe(II) Sorption on Hematite: New Insights Based on Spectroscopic Measurements. Environ. Sci. Technol. 2007, 41, 471-477. [CrossRef]

24. Frierdich, A.J.; Helgeson, M.; Liu, C.; Wang, C.; Rosso, K.M.; Scherer, M.M. Iron Atom Exchange between Hematite and Aqueous Fe(II). Environ. Sci. Technol. 2015, 49, 8479-8486. [CrossRef]

25. Catalano, J.G.; Fenter, P.; Park, C.; Zhang, Z.; Rosso, K.M. Structure and Oxidation State of Hematite Surfaces Reacted with Aqueous Fe(II) at Acidic and Neutral PH. Geochim. Cosmochim. Acta 2010, 74, 1498-1512. [CrossRef]

26. Jeon, B.-H.; Dempsey, B.A.; Burgos, W.D.; Royer, R.A. Reactions of Ferrous Iron with Hematite. Colloids Surf. A Physicochem. Eng. Asp. 2001, 191, 41-55. [CrossRef] 